DOI https://doi.org/10.18551/rjoas.2020-10.08

\title{
INFORMATION TECHNOLOGY MODERATION (E-SPT, E-BILLING, E-FILING) AND PERSONALITY TYPES ON THE EFFECT OF ROLE OVERLOAD IN TAX CONSULTANT BURNOUT IN BALI PROVINCE, INDONESIA
}

\author{
Astika Ida Bagus Putra*, Dwirandra A.A.N.B., Kresnandra Agung \\ Study Program of Accounting, Faculty of Economics and Business, University of Udayana, \\ Bukit Jimbaran, Indonesia \\ *E-mail: astikaputra18@gmail.com
}

\begin{abstract}
The purpose of this study was to determine the effect of role overload on burnout. The specific objective of this study was to determine the ability of contingency factors, such as information technology / IT taxation (E-SPT, E-Billing, E-Filing) and Personality Type, to moderate the effect of role overload on burnout. The study population was a registered tax consultant who worked at the Tax Consultant Office / KKP in Bali Province using a purposive sampling method. The data were collected using a questionnaire from previous researchers that was modified and had met the requirements for the validity and reliability of the instrument. Then, the data collected were tabulated and several tests and analyzes were carried out, including 1) classical assumption tests to ensure compliance with the Best Linear Unbiased Estimator (BLUE) requirements, 2) Descriptive Statistical Analysis, 3) model feasibility test ( $F$ test), 4) determination coefficient analysis (Adj. $R^{2}$ ), and 5 ) research hypothesis test (t-test) for both partial and moderate effects. This study concluded that role overload has a significant negative effect on burnout. IT taxation (E-SPT, E-Billing, E-Filing) significantly weakens the effect of role overload on burnout. Personality types weaken the effect of role overload on burnout, but not significantly.
\end{abstract}

\section{KEY WORDS}

Role overload, tax information technology, personality type, burnout.

Sri Mulyani in a press conference in Jakarta, Wednesday, January 2, 2019, said that the tax ratio (tax ratio) experienced a significant improvement in 2018 compared to 2017, from $10.7 \%$ to $11.5 \%$ of GDP. This means that all tax reforms carried out by the government have increasingly shown results (Warta Ekonomi.co.id., 3-1-2019). Despite the increase, this achievement is still lower than the tax ratio for Southeast Asian countries except for Myanmar. This low tax ratio cannot be attributed only to the government, public awareness of paying taxes is also still low, and also the less optimal role of tax consultants due to the prolonged dual agency status which results in, among other things, the tax consultant experiencing burnout.

The cause of burnout experienced by tax consultants is the role overload experienced by individuals in an organization. Cordes, L., Dougherty, \& W., (1993) said that one of the causes of burnout was role overload. Mondy, et al (1990:490) states that role overload is a more complex type of role conflict. Gratia (2014) emphasizes that role overload occurs when employees have to carry out reasonable tasks if they are done one by one, but these tasks become more difficult if they are carried out simultaneously within a specified period.

However, the reality of empirical research reveals inconsistent results on the effect of role overload on burnout. Fogarty et al (2000), Murtiasri \& Ghozali, (2006), Jones (2010), Tamaela (2011), Utami \& Nahartyo (2013), Wiryathi et al. (2014), Andy Pradana (2016), found the effect of role overload on burnout. Meanwhile, research conducted by Riantiningtyas (2009) found that auditor burnout is influenced by role conflict, while role ambiguity and role overload do not affect auditor burnout. Ferdiansyah and Ira Rachmawati Purnima (2011) found that role overload did not affect burnout.

The inconsistency of this result is presumably due to other factors that influence the relationship between the independent variable and the dependent variable. Govindarajan 
(1986) states that there may not be any unified research results depending on certain factors or better known as contingent factors. Murray (1990) explains that to reconcile conflicting results, a contingency approach is needed to identify other variables that act as moderators or mediators in the research model.

Several contingency factors can be expected to moderate the effect of role overload on tax consultant burnout. Researchers are interested in knowing the moderating effect of external factors, namely information technology / IT taxation which includes e-SPT, e-billing, and e-filing. Researchers also want to reveal the role of internal factors, namely the tax consultant personality type. Research which at the same time wants to reveal the moderating role of internal and external factors, as well as the role of tax IT as an effort to confirm the effectiveness of the role of national tax administration reform will provide significant added research value.

\section{LITERATURE REVIEW}

Role theory tries to explain the interactions between individuals in organizations focusing on the roles that are played. In a theater performance, an actor must act like a certain character. When carrying out their roles, these figures are expected to behave in a certain way (Sarwono, 2015). Each role that is carried out has an identity that distinguishes each individual regarding who and how the individual acts in certain situations. According to role theory, a person has a certain role, for example, as a lecturer, doctor, student, parent, and so on. Therefore, a person is expected to behave by this role (Mustafa, 2011). This research was conducted to reveal the extent to which tax consultants can carry out their role when faced with the dual agency dilemma, whether the role overload is perceived as normal or so strong that it causes burnout.

The study of attribution was initially carried out by Heider in 1958. Attribution theory developed from his writing entitled "Native Theory of Action", which is a conceptual framework used by people to interpret, explain, and predict a person's behavior. According to Heider (1958), every individual is essentially a pseudo scientist who seeks to understand the behavior of others by collecting and combining pieces of information until they come to a plausible explanation of why others behave. Heider (1958) in Suartana (2010) states that attribution theory studies the process of how a person interprets an event and studies how a person interprets the reasons or causes of their behavior. Attribution theory states that when individuals observe a person's behavior, they try to determine whether it is caused internally or externally (Robbins, 2008). Attribution can be divided into two, namely Internal Attribution, namely a person's behavior arises due to internal factors such as attitudes, certain traits, or other internal aspects and External Attribution, namely a person's behavior arise due to circumstances or the outside the person concerned (Sarwono, 1999). According to Robbins (2008), the internal or external determination of behavior depends on three factors, namely specificity, consensus, and consistency. In this research, the researcher wants to confirm the moderating role of internal factors - personality type and external factors - IT taxation (eSPT, e-billing, and e-filing).

Affective event theory is a theory which states that events at work that cause emotional reactions in employees will affect attitudes and behavior in the workplace. The work environment in question is all matters relating to tasks, level of autonomy, job demands, and requirements for expressing emotional work (Robbins, Judge, \& A, 2008). Events that occur at work can trigger both positive and negative reactions. These events can be responded to with greater or lesser intensity depending on the influence of the personality and mood of the individual. These emotions can trigger burnout and will affect performance and satisfaction such as organizational commitment, level of effort, intention to quit work, and irregularities in the workplace (Robbins et al., 2008). Of course, effective event theory is very relevant to this research, one of which is to examine the moderating role of personality types on the effect of role overload on burnout. A tax consultant with an extrovert personality type will certainly be better able to control the overload conditions that are common in this profession so that it 
can better prevent burnout. How is the reality, still have to wait for the results of the moderation regression test that will be carried out in this research.

TAM (Technology Acceptance Model) which was first introduced by Davis (1989) is a type of theory that uses a behavioral theory approach which is widely used to study the process of information technology adoption and explains that the use of information systems will be influenced by usefulness variables and ease of use variables. TAM is very relevant to this research because it will examine the role of IT taxation (e-SPT, e-billing, e-filing) in moderating the effect of role overload on tax consultant burnout. If IT Taxation is felt to be easy to use and usefulness, of course, it will be able to reduce the overload faced and will have an impact on reducing burnout. How is the reality, of course, interesting to reveal through the moderation test that will be carried out in this research?

Burnout is a term that was first put forward by Freudenberger, (1974) and has been widely researched in the literature on health and applied psychology (Almer \& Kaplan, 2002). Burnout is a fatigue syndrome, both physically and mentally which will have negative effects on oneself, lack of concentration, and negative work behavior (Pines \& Maslach, 1993). Burnout is a representation of a specific psychological stress syndrome, which is a negative response that arises due to work pressure or stressors (Cordes et al., 1993). Burnout is also defined as a condition that appears from time to time and is characterized by emotional exhaustion and a combination of negative traits (Kreitner \& Kinicki, 2005). Maslach \& Jackson, (1981) define burnout as a syndrome of psychological and emotional exhaustion, depersonalization, and decreased work performance that arises among individuals who work with other people.

Burnout consists of three dimensions (Freudenberger, 1974; Cordes et al, 1993; Maslach et al, 2001; (Almer \& Kaplan, 2002), (Murtiasri \& Ghozali, 2006), namely emotional exhaustion (emotional exhausted), depersonalization (depersonalization), and decreased performance (reduces personal accomplishment). Emotional exhaustion is a dimension of burnout which is the deepest feeling and energy as a result of excessive emotional and psychological demands where emotional exhaustion is characterized by loss of feeling and attention, trust, interest, and enthusiasm (Ray \& Miller, 1994). These excessive demands come from work tasks that require creativity, innovation, solutions, and high passion when professionals work for clients under time pressure (Jackson \& Milliron, 1986).

Role overload, namely qualitative role load, and quantitative role load. Qualitative role load when an individual feels that his / her expertise cannot meet the demands assigned to it, while quantitative role load occurs when an individual has difficulty completing a task within a predetermined time (Bhanugopan and Fish 2006). Role overload is experienced when employees are faced with more work in the time available (Robbins et al., 2008). Schick, Gordon, \& Haka, (1990) said that when an employee has too much work, but it is not by the available time, it can cause role overload. Yustrianthe, (2008) states that professionals who experience prolonged role overload can experience a tendency to evaluate themselves negatively about their achievements. During the busy season, tax consultants have the responsibility to do fieldwork and find the required data from clients. Busy season in the tax consulting profession usually occurs during the annual report or the annual SPT period.

Forgaty et al. (2000) \& Murtiasri \& Ghozali, (2006) found a positive relationship between role overload on burnout. Jones, (2010), Tamaela (2011), Utami \& Nahartyo (2013) found a positive relationship between role overload on burnout. Andy Pradana, (2016) states that role overload also has a positive effect on tax consultant burnout.

Through the conceptual description and empirical research results above, it can be seen that when there is so much work (in quantity and quality) that must be completed when the time available is limited, an individual such as a tax consultant is very likely to be in an overload condition. A prolonged situation of tax consultant overload, especially during the busy season, such as: during the annual report or the annual SPT period, and being chased by deadlines, it can result in excessive physical and mental fatigue which is called burnout. 
Therefore, based on the conceptual description, empirical research results, and logical thinking framework that has been described, the following research hypothesis can be developed:

$\mathrm{H}_{1}$ : Role overload has a positive effect on tax consultant burnout.

The government provides applications that can be used by taxpayers to fill and report Tax Returns (SPT) quickly, precisely, and accurately to realize a modern tax administration system. E-SPT is the submission of Tax Returns (SPT) in digital form to the Tax Service Office (KPP) electronically or using computer media (Pandiangan, 2008: 35). The government provides an application that can be used by Corporate Taxpayers to fill and report Tax Returns (SPT) quickly, precisely, and accurately to realize a modern tax administration system.

Research related to the application of e-SPT has been conducted by several researchers, such as Nenny Sukmarini (2007), Hikmat Rakhmansyah (2010), and Rendy Suryadi (2012). They found that the application of e-SPT affects the effectiveness of processing tax data.

For tax consultants who are given the mandate by their clients to complete their tax affairs, it is certainly very easy and/or facilitated by the existence of e-SPT because they can work on large volumes of taxation services in a relatively efficient time. Thus, the tax consultant's burnout as a result of the excessive workload (role overload) will be relatively reduced.

Based on the conceptual description, the results of empirical research, the logical framework above, the following research hypothesis can be developed: burnout.

$\mathrm{H}_{2}$ : IT taxation (E-SPT) weakens the positive effect of role overload on tax consultant

E-billing is an electronic payment method using a billing code. Electronic payment transactions or tax deposits are made through a bank or perception post using the billing code. All Tax Service Offices in Indonesia have participated in the trial implementation of the electronic tax payment system (billing system) since April 12, 2013, by the Decree of the Directorate General of Taxes Number KEP - 359 / PJ / 2013 concerning the appointment of Tax Service Offices and Taxpayers in the framework of testing the Application of the Electronic Tax Payment System (billing system) in the State Revenue Module System (Andrian et al., 2013).

This E-billing application guarantees the security of electronic transactions between taxpayers and the Directorate General of Taxes. Furthermore, this application makes it easy to pay taxes electronically with all the advantages including being easy, fast, and accurate. It is said to be easy because, in the tax payment process, depositors no longer need to bother filling out paper deposits manually. The E-billing system simplifies the data entry process, minimizes the potential for human errors in recording payment and deposit data by perception bank or postal officers.

Several researchers have conducted research related to the implementation of this ebilling. Agus et al (2014) in their research found that perceptions of usability, ease of use, and attitudes of use influence the behavioral interest in using the Billing System. Arif (2015) and Resky (2015 found that the behavior of using e-billing was driven by the perception of the usefulness and ease of e-billing.

Tax consultants who are given the mandate by their clients to settle their tax affairs are certainly greatly facilitated by the existence of this Taxation IT. Thus, the tax consultant's burnout as a result of the excessive workload (role overload) will be relatively reduced. Based on the conceptual description, the results of empirical research, the logical framework above, the research hypothesis can be developed as follows: burnout.

$\mathrm{H}_{3}$ : Taxation IT (e-billing) weakens the positive effect of role overload on tax consultant

E-filling according to the Regulation of the Directorate General of Taxes Number PER1 / PJ / 2014 is a way to electronically submit notification letters (SPT) online and in realtime, which is accessed on the official website of the Directorate General of Taxes (https: //www.pajak.go. id). With this e-Filing, it is expected that taxpayer compliance in reporting 
SPT can be improved. This system is expected to be more effective and efficient in terms of time for taxpayers to fulfill their obligations because taxpayers do not need to come to the tax service office so that taxpayers can be facilitated (Candra, 2013).

Nurhidayah (2015) stated that E-Filing is a way of submitting SPT through an online and real-time system. E-Filing, of course, can reduce the cost and time required by taxpayers to prepare, process, and report tax returns to the tax office, because with the convenience of using the internet, this can be done effectively and efficiently. Taxpayers report their SPT, so it is more accurate, effective, and efficient.

Several researchers have conducted research related to the application of e-filing. Research conducted by Djamaran (2010) found that the effectiveness of the e-filing system has been achieved because the goal of this system has been achieved, namely reducing the manual recording process at the tax office. Laili (2012) from research shows that e-filing increases the effectiveness of tax reporting. Sugiharti et al., (2015) revealed that the e-filing system is feasible as a means of tax reporting and results in the satisfaction felt by individual taxpayers in reporting payable taxes.

Tax consultants who are mandated by their clients to settle their tax matters related to SPT reporting will certainly be greatly relieved and / or facilitated by the existence of this Taxation IT. Thus, the tax consultant's burnout as a result of the excessive workload (role overload) will be relatively reduced. Based on the conceptual description, the results of empirical research, the logical framework above, the research hypothesis can be developed as follows:

$\mathrm{H}_{4}$ : Taxation IT (e-filing) weakens the positive effect of role overload on tax consultant burnout.

Jung (1960) and Feist \& Feist (2000) classified individual personality types into two (2) namely extrovert and introvert. Extroverted individuals have an objective or an impersonal way of looking at the world, while introverts are essentially subjective or individual ways of seeing things.

This study aims to reveal the ability of the tax consultant personality type in dealing with role overload so that it can control the burnout conditions experienced. In this regard, further research will reveal the role of extrovert personality types. Suryabrata (2003) states that extroverts are influenced by the objective world, namely the world outside the individual. His thoughts, feelings, and actions are determined by the environment, both social and nonsocial. Someone who has an extrovert personality has a positive attitude towards a society which means being open, sociable, and having smooth relationships with other people. The extrovert personality is a personality that has the characteristics of being able to socialize and be active. Extrovert personality focuses on an individual who is friendly, assertive and interacts positively with others (Suliman, Abdel Rahman, \& Abdalla, 2010).

Research conducted by Argyle \& Lu, (1990) and Hills and Argyle, (2001) stated that the value of extroversion has a positive and significant correlation with happiness and positive effects so that the level of stress in extroverted individuals tends to be lower when compared to ambiverts and introverts. Arifianti's research (2008) found that individuals who are more likely to be extroverted, the lower the burnout will be, and individuals who are more likely to be introverted, the higher the burnout. Azizah's research (2016) reveals that students with extrovert personality types tend to be tolerant of stressors so they have lower stress levels than individuals with introverted personalities.

Tax consultants who are in a role overload will be more able to control the situation and workload faced if they have an extrovert personality type so that in the end they are relatively able to control prolonged burnout. Thus, based on the conceptual description, the results of empirical research, the logical framework above, the research hypothesis can be developed as follows: burnout.

$\mathrm{H}_{5}$ : Personality type weakens the positive influence of role overload on tax consultant 


\section{METHODS OF RESEARCH}

This research is an associative study that seeks to confirm the alleged effect of role overload on burnout and specifically wants to reveal the presumed role of moderating $\mathrm{TI}$ Perjakan and personality types on the effect of role overload on burnout.

The object of this research is the tax consultant burnout with the research location being the Tax Consultant Office / KKP in Bali Province. The population of this study is 2007 tax consultants who work at $25 \mathrm{KKP}$ based on the 2018 Directory of the Indonesian Tax Consultants Association. The research sample was determined by purposive sampling method with the following criteria: 1) Are employees who do work in the taxation field, and 2) Have work experience at least one year at the KKP.

The data collection method used in this research is a questionnaire which is a data collection technique that is carried out by giving a set of questions or written statements to respondents to answer (Sugiyono, 2017). In this study, the questionnaire was distributed directly to the target respondents to each KKP in Bali.

Validity testing shows the extent to which the measuring instrument can be used to measure what should be measured (Sugiyono, 2017). The validity test can be done by correlating the factor score with the total score and if the correlation coefficient for each factor is positive 0.3 and above, the questionnaire or statement is declared valid.

The reliability test is a test to determine the extent to which the results of measurement remain consistent if the measurement is carried out more than once against the same symptom using the same measuring instrument. To see the reliability of these instruments, the Cronbach Alpha of each instrument will be calculated at the SPSS output. The variable is said to be reliable if the Cronbach Alpha value is $\geq 0.70$ (Ghozali, 2016).

Before testing multiple linear regression analysis, the classic assumption test is carried out first. The classical assumption test is needed to make the regression model an unbiased estimation tool, the classic assumption tests used in this study are:

The normality test aims to test whether, in the regression model, the residual variable has a normal or abnormal distribution. A good regression model is a model with normally distributed residues (Ghozali, 2016). The method used is the Kolmogorov-Smirnov statistic. If Asymp. Sig (2-tailed) is greater than the level of significance of 0.05 used, it can be concluded that the residuals of data are said to be normally distributed.

The multicollinearity test aims to test whether the regression model found a correlation between the independent variables. A good regression model should not correlate with the independent variables. Multicollinearity can be seen from the tolerance value or variance inflation factor (VIP). If the tolerance value is greater than $10 \%$ or the VIP is less than 10 , it can be said that the model is free from multicollinearity problems (Ghozali, 2016).

The heteroscedasticity test aims to test whether in the regression model there is an inequality of variance from the residuals of one observation to another. If the residual variance from one observation to another is constant, it is called homoscedasticity and if it is different it is called heteroscedasticity. A good regression model is a model with homoscedasticity or heteroscedasticity does not occur. If a regression model contains heteroscedasticity symptoms, it will give deviant results. This test can be analyzed through the Glejser test by seeing the level of significance above 0.05 , so the regression model is free from heteroscedasticity problems (Ghozali, 2016).

After testing the classical assumptions of the research sample, verification of data analysis will be carried out using Moderated Regression Analysis (MRA) techniques, with the following equation:

$$
B O=\alpha+\beta_{1} R O+E S+\beta_{3} E B+\beta_{4} E F+\beta_{5} T K+\beta_{6} R O . E S+\beta_{7} R O . E B+\beta_{8} R O . E F+\beta_{9} R O . T K+e
$$

Where: $\mathrm{BO}=$ Burnout; $\mathrm{A}=$ Constant; $\beta_{1,2,3,4,5,6,7,8}=$ Regression coefficients of the independent and interaction variables; $\mathrm{RO}=$ Role Overload; $\mathrm{ES}=\mathrm{IT}$ Taxation (e-SPT); $\mathrm{EB}=\mathrm{IT}$ Taxation (e-billing); EF = IT Taxation (e-filing); TK = Personality type; RO.ES = interaction of Role Overload and IT Taxation (e-SPT; RO.EB = interaction of Role Overload 
and IT Taxation (e-billing); RO.EF = interaction of Role Overload and IT Taxation (e-filing); RO. TK = interaction of Role Overload and Personality Types.

$e=$ error term

\section{RESULTS OF STUDY}

Minister of Finance Regulation Number 111 / KMK.03 / 2014 explains that tax consultants have a role to provide professional services to taxpayers to fulfill their tax rights and obligations to comply with applicable laws by assisting taxpayers in calculating, paying, and report their tax obligations. Meanwhile, the tax consulting office is a business unit that has obtained a license from the relevant agency, as a forum for tax consultants to carry out their services. Based on the 2019 IKPI directory, in Bali province, there are 34 Tax Consultant Offices.

Respondents in this study were all tax consultants in tax consulting offices in Bali Province. This study uses the purposive sampling technique, namely the technique of determining the sample with certain considerations, where the tax consultants who are sampled are tax consultants who have at least 1 year of work experience. Based on this, the number of respondents in this study was 146 people. This research questionnaire began to be distributed on January 20, 2019 - February 20, 2019.

Data collection was carried out by visiting respondents directly to submit and collect questionnaires again. Of the 210 questionnaires distributed by researchers, 180 copies of questionnaires were returned and 34 of them had less than 1 year of experience. Thus, the number of questionnaires that can be processed is 146 questionnaires. A detailed description of the questionnaire can be seen in table 1.

Table 1 - Return and use of questionnaire

\begin{tabular}{|l|l|}
\hline Explanation & Amount \\
\hline Returns and Use of Questionnaires & 210 \\
\hline Non-returned questionnaire & 30 \\
\hline Questionnaires that do not meet the criteria (working period <1 year) & 34 \\
\hline Questionnaires that can be used & 146 \\
\hline Rate of Return (response rate) & $86 \%$ \\
\hline Useable response rate & $70 \%$ \\
\hline
\end{tabular}

Source: Primary data processed (2019).

Based on Table 1, it can be seen that of the 210 questionnaires distributed, 180 questionnaires were returned, and 34 questionnaires did not meet the purposive sampling criteria, so the number of questionnaires that could be used was 146 questionnaires. The calculation of these data resulted in a response rate of 86 percent and a useable response rate of 70 percent.

The validity test is carried out to determine the extent to which the measuring instrument can be used to measure what should be measured (Sugiyono, 2017: 121). An instrument will be said to be valid if the Pearson correlation value with the total score is above 0.30 (Sugiyono, 2017). Based on the results of the instrument validity test, it can be seen that the Pearson correlation of each respondent's statement is greater than 0.30 and the significance value is less than 0.05 . Thus it can be said that all respondent's statements in the questionnaire have met the valid requirements so that they are suitable for use in research.

A reliability test is used to measure whether the instrument used several times to measure the same object will produce the same data (Sugiyono, 2017). If an instrument has a Cronbach Alpha value greater than 0.70, the instrument is said to be reliable. Based on the results of the instrument reliability test, it can be seen that all research instruments, namely Use of Information Technology, Relevance of Information Technology, Satisfaction of Accounting Information Systems, Effectiveness of Accounting Information Systems, and 
Employee Performance have a Cronbach's Alpha coefficient greater than 0.70 so that it can be said to be reliable and fit for use in research.

Before doing multiple linear regression analysis, the regression model that is made must go through the classical assumption test first so that the resulting equation meets the BLUE (Best, Linear, Unbias, Estimator) rules. If the classical assumption test is not carried out before data processing, the resulting regression model equation is doubtful for its ability to produce accurate predictions. A good regression model is a regression model in which there are no data problems with abnormal distribution, multicollinearity problems, and heteroscedasticity problems. The results of the classical assumption test can be presented as follows:

The data normality test was carried out using the Kolmogorov-Smirnov method (Ghozali, 2017). If the value is Asymp. Sig (2-tailed) is greater than the level of significance used, namely 0.05 , so the data in the study are said to be normally distributed. Based on the results of the data normality test, it can be seen that the coefficient value of Asymp.Sig. (2tailed) 0.066 is greater than the alpha value of 0.05 . This shows that the variables RO, ES, $\mathrm{EB}, \mathrm{EF}, \mathrm{TK}, \mathrm{BO}$ are normally distributed.

The multicollinearity test aims to test whether the regression model finds a correlation between independent variables (Ghozali, 2017). The multicollinearity test results show that all independent variables in this study, namely the use of information technology, the relevance of information technology, the satisfaction of accounting information systems, the effectiveness of accounting information systems show a tolerance value greater than 0.10 and VIF less than 10. This indicates that there are no symptoms of multicollinearity between the independent variables in the multiple regression model.

The heteroscedasticity test aims to test whether in the regression model there is an inequality of variants from the residuals of one observation to another. A good regression model is one that does not contain heteroscedasticity symptoms or has a homogeneous variant. The results of the heteroscedasticity test show that all independent variables in this study, namely role overload / RO, e-SPT, e-billing, e-invoicing, and personality level, show the sig value. each of $0.792 ; 0.860 ; 0.806 ; 0.831$, and 0.858 which is greater than 0.05 . This means that there is no influence between the independent variables on absolute residuals, so the regression model used does not contain heteroscedasticity symptoms.

Descriptive statistics in this study were tested to provide information about the characteristics of the research variables. The minimum value indicates the smallest or lowest value in a data set. The maximum value indicates the largest or highest value in a data set. The average (mean) is the most common way to measure the central value of a data distribution under study. Standard deviation is a measure that shows the standard deviation of the observed data from the average data (Ghozali, 2017).

Table 2 - Descriptive Statistics

\begin{tabular}{|c|c|c|c|c|c|}
\hline VARIABEL & $\mathrm{N}$ & Minimum & Maximum & Mean & Std. Deviation \\
\hline RO & 146 & 1 & 5 & 2.79 & .062 \\
\hline ES & 146 & 1 & 6 & 5.16 & .707 \\
\hline EB & 146 & 1 & 6 & 5.16 & .629 \\
\hline EF & 146 & 1 & 6 & 5.12 & .706 \\
\hline TK & 146 & 1 & 5 & 3.51 & .645 \\
\hline BO & 146 & 1 & 5 & 2.80 & .832 \\
\hline Valid N (listwise) & 146 & \multicolumn{5}{|c|}{-} \\
\hline
\end{tabular}

Based on table 2 above, several things can be seen as follows:

- The average value of RO or role overload of respondents is low, namely 2.79 from the Likert scale of 6 , as well as the average value of BO or burnout of respondents which is 2.80 from the maximum Likert scale of 6 ;

- The average value of ES or e-SPT (5.16), EB or e-billing (5.16), and EF or e-invoice (5.12) is very high even though it has not reached the maximum Likert scale of 6 ; 
- The personality type / TK score is moderate, which is 3.51 from a maximum Likert scale of 6.

Research data processing has been carried out using SPSS with moderated regression analysis / MRA techniques and the results are as presented in table 3.Based on this table, a moderated regression equation model can be developed to estimate burnout / $\mathrm{BO}$ and test the research hypothesis.

$\mathrm{H}_{1}$ : Role overload has a positive effect on tax consultant burnout.

Based on table 3, it can be seen that the results of the hypothesis test (t-test) of the effect of the RO variable on BO obtained the Sig. 0.014 with the unstandardized coefficients beta value of 0.429 , which means that $R O$ has a significant positive effect on $B O$ or role overload as perceived by KAP auditors in Bali to increase the burnout of tax consultants in Bali. The results of this test accept the $\mathrm{H}_{1}$ hypothesis which states that Role overload has a positive effect on tax consultant burnout. Thus the test results accept hypothesis $\mathrm{H}_{1}$.

Table 3 - MRA Test Results

\begin{tabular}{|c|c|c|c|c|c|c|}
\hline & \multirow[t]{2}{*}{ Model } & \multicolumn{2}{|c|}{ Unstandardized Coefficients } & \multirow{2}{*}{$\begin{array}{c}\text { Standardized } \\
\text { Coefficients } \\
\text { Beta }\end{array}$} & \multirow[t]{2}{*}{$\mathrm{t}$} & \multirow[t]{2}{*}{ Sig. } \\
\hline & & B & Std. Error & & & \\
\hline \multirow{10}{*}{1} & (Constant) & 14,581 & 15,502 & & 941 & ,349 \\
\hline & $\mathrm{RO}$ &, 429 & 1,818 & ,149 & ,236 &, 014 \\
\hline & ES &,- 210 &,- 570 &,- 098 & ,369 &, 023 \\
\hline & EB &,- 350 &,- 630 &,- 193 &, 555 &, 012 \\
\hline & EF &,- 395 &,- 436 &,- 244 & ,905 &, 017 \\
\hline & TK &,- 052 &,- 200 &,- 041 & ,262 &, 034 \\
\hline & RO.ES &,- 030 &,- 067 & ,347 & ,439 &, 033 \\
\hline & RO.EB &,- 031 &,- 066 & ,479 & , 473 & ,022 \\
\hline & RO.EF &,- 052 &,- 041 & ,802 & 1,279 &, 027 \\
\hline & RO.TK &,- 055 &,- 024 & ,792 & 2,258 &, 056 \\
\hline
\end{tabular}

Dependent Variable: $B O$. burnout.

$\mathrm{H}_{2}$ : IT taxation (E-SPT) weakens the positive effect of role overload on tax consultant

Based on table 3 above, it can be seen that the results of the hypothesis test (t-test) affect the RO variable. The ES on BO obtained the Sig. 0.033 with the unstandardized coefficient beta value of -0.030 which means that the interaction of $R$ and ES has a significant negative effect on BO or in the words that E-SPT has a significant positive effect on BO or E-SPT to reduce the burnout of tax consultants in Bali. Thus the results of this hypothesis test accept the research hypothesis $\mathrm{H}_{2}$. burnout.

$\mathrm{H}_{3}$ : Taxation IT (e-billing) weakens the positive effect of role overload on tax consultant

Based on table 3 above, it can be seen that the results of the hypothesis test (t-test) of the effect of the RO.EB variable on BO obtained the Sig. 0.022 with the unstandardized coefficients beta value of -0.031 , which means that the RO.EB variable has a significant negative effect on $\mathrm{BO}$ or in the words that E-Billing significantly weakens the positive effect of role overload on tax consultant burnout in Bali. Thus the results of this hypothesis test accept the research hypothesis $\mathrm{H}_{3}$. burnout.

$\mathrm{H}_{4}$ : Taxation IT (e-filing) weakens the positive effect of role overload on tax consultant

Based on table 3 it can be seen that the results of the hypothesis test (t-test) of the effect of the RO.EF variable on BO obtained the Sig. 0.027 with the unstandardized coefficients beta value of -0.052 which means that the RO.EF variable has a significant negative effect on $\mathrm{BO}$ or in the words that E-Filling significantly weakens the positive effect of role overload on the burnout of tax consultants in Bali. Thus the results of this hypothesis test accept the research hypothesis $\mathrm{H}_{4}$.

$\mathrm{H}_{5}$ : Personality type weakens the positive influence of role overload on tax consultant burnout. 
Based on table 3 it can be seen that the results of the hypothesis test (t-test) of the effect of the RO.TK variable on BO obtained the Sig. 0.056 with the unstandardized coefficients beta value of -0.055 which means that the RO.TK variable has a negative and insignificant effect on $\mathrm{BO}$ or in the words that personality type weakens but does not have a significant positive effect on role overload on tax consultant burnout in Bali. Thus the results of this hypothesis test reject the research hypothesis $\mathrm{H}_{4}$.

Based on table 3 above, it can be seen the magnitude of the constants, the beta coefficient of each independent and interaction variable, and an estimation MRA model equation is developed, with the following details:

- The constant is 14,581 ;

- Beta / B coefficients (Unstandardized Coefficients) for each of the variables RO, ES, EB, EF, TK, RO.ES, RO.EB, RO.EF, RO.TK, respectively $-0,429,0,210,0,350$, $0,395,0,052,0,030,0,031,0,052$, and 0,055;

- Based on the data points 1 and 2 above, an MRA model of BO / Burnout estimation can be developed, as follows:

$$
\begin{aligned}
& \mathrm{BO}=14,581-0,429 \mathrm{RO}+0,210 \mathrm{ES}+0,350 \mathrm{~EB}+0,395 \mathrm{EF}+0,052 \mathrm{TK}+0,030 \mathrm{RO} . \mathrm{ES}+0,031 \mathrm{RO} . \mathrm{EB}+ \\
& 0,052 \text { RO.EF }+0,055 R O . T K+e
\end{aligned}
$$

The $\mathrm{F}$ test shows model testing to ensure that all (independent) predictor variables can predict/explain the dependent variable (Ghozali, 2017). The $F$ test can be seen by looking at the results of the regression carried out through the SPSS program by comparing the significance level of $F$ with the $5 \%$ degree of confidence $(\alpha=0.05)$. Based on table 4 , it can be seen that the value produced by $F$ calculated is 2.025 with a significance level of 0.037 which is smaller than $\alpha=0.05$. Thus, the burnout prediction model (BO) such as equation 2 above is feasible to be used to estimate the burnout of tax consultants in Bali.

Table 4 - Model Feasibility Test Results

\begin{tabular}{|c|c|c|c|c|c|c|}
\hline \multicolumn{2}{|c|}{ Model } & Sum of Squares & df & Mean Square & $\mathrm{F}$ & Sig. \\
\hline \multirow{3}{*}{1} & Regression & 211,842 & 5 & 42,368 & 2,025 &, $037^{b}$ \\
\cline { 2 - 7 } & Residual & 2928,505 & 140 & 20,918 & \multirow{2}{*}{-} & - \\
\cline { 2 - 8 } & Total & 3140,347 & 145 & - & & - \\
\hline
\end{tabular}

a. Dependent Variable: ABS_RES.

b. Predictors: (Constant), TK, EF, RO, ES, EB.

Table 5 - Coefficient of Determination $\left(\mathrm{R}^{2}\right)$

\begin{tabular}{|l|l|l|l|l|}
\hline Model & R & R Square & Adjusted R Square & Std. Error of the Estimate \\
\hline 1 &, $472^{\mathrm{a}}$ &, 570 &, 568 & 4,57361 \\
\hline
\end{tabular}

Predictors: (Constant), TK, EF, RO, ES, EB

The coefficient of determination (R2) test is used to measure the model's ability to explain the variation in the dependent variable that can be explained by the independent variable. The R-Square value (coefficient of determination) is between zero and up to one. The R-Square value that is close to one means the ability of the independent variables to provide almost all the information needed to predict the variation in the dependent variable (Ghozali, 2017). Based on table 5, it can be seen that the R-Square value is 0.570 , which means that 57.0 percent of the burnout variation can be explained by the independent variable in the model, the remaining 47.0 percent is explained by other variables not included in this research model.

\section{CONCLUSION AND RECOMMENDATIONS}

Based on hypothesis testing and discussion of the research results previously described, it can be concluded as follows:

1. Role overload significantly increases tax consultant burnout; 
2. Taxation IT (E-SPT) weakens the positive effect of role overload on tax consultant burnout;

3. Taxation IT (E-Billing) weakens the positive effect of role overload on tax consultant burnout;

4. Taxation IT (E-Filing) weakens the positive effect of role overload on tax consultant burnout;

5. Personality type attenuates the positive influence of role overload on tax consultant burnout but it is not significant.

Based on the discussion that has been done, the following suggestions can be made:

1. KKP in Bali to improve a better work system, such as the existence of clear supervision or direction and can equalize perceptions of tax science and the company's vision and mission to implement a uniform work system;

2. KKP needs to increase clearer work assignments or according to positions and to further clarify the job descriptions of each role holder with better supervision or direction;

3. Based on the research results, it shows that extrovert personality weakens the influence of role stress on tax consultant burnout in Bali Province. Next, to minimize the incidence of tax consultant burnout in Bali to implement better time management so that the work can be completed on time;

4. Further research can be developed through experimental studies or a combination of questionnaire and interview methods to obtain more information from respondents to maximize extracting data and information needed for research;

5. Further research can be carried out in a period, namely March and April during the peak season to match the results expected by the researcher in examining the burnout situation;

6. For the next researcher, it is necessary to examine the role of other contingency factors that are thought to reduce the negative effect of time budget pressure on audit quality, such as fraud audit training, whistleblowing intention, and professional skepticism, and so on.

\section{REFERENCES}

1. Agus Andrian. Kertahadi and Heru Susilo. 2014. Analisis Pengaruh Persepsi Kegunaan, Persepsi Kemudahan, and Sikap Penggunaan Terhadap Minat Perilaku Penggimaan Billing System (Studi Pada Wajib Pajak Kantor Pelayanan Pajak Pratama Malang Utara). Jumal Skripsi Program Studi Perpajakan, Jurusan Administrasi Bisnis, Fakultas IImu Administrasi Universitas Brawijaya.

2. Almer, E. ., \& Kaplan, S. . (2002). The Effect of Flexible Work Arrangements on Stressors, Burnout, and Behavioral Job Outcomes in Public Accounting. Behavioral Research in Accounting, 14, 1-34.

3. Andy Pradana, M. (2016). Pengaruh Role Conflict, Role Ambiguity, Role Overload, and Job Insecurity pada Burnout Konsultan Pajak di Kantor Konsultan Pajak Se- Provinsi Bali. Udayana.

4. Argyle, M. (2001). The Psychology of happiness. New York: Routledge.

5. Argyle, M., \& Lu, L. (1990). The Happiness of Extraverts. Personality and Individual Differences, 11, 1011-1017.

6. Arifianti, R. P. (2008). Hubungan Antara Kecenderungan Kepribadian Ekstrovert Introvert Dengan Burnout Pada Perawat. Artikel Ilmiah.

7. Arif, Setiawan. 20\5Analisis Faktor-Faktor Yang Mempengaruhi Perilaku Penggunaan Sistem E-Filling Oleh Wajib Pajak Orang Pribadi Dalam Penyampaian SPT Masa Secara Online and Realtime (Studi Kasus pada KPP Pratama Semarang Candisari 2014).

8. Azizah, yasinta nurul. (2016). Perbedaan Antara Tipe Kepribadian Ekstrovert and Introvert Dengan Tingkat Stres Pada Mahasiswa Fakultas Hukum Universitas Muhammadiyah Surakarta. Nasional, 8(3), 4-13.

9. Andrian, Agus, Kertahadi and Heru Susilo. 2013. Analisis Pengaruh Persepsi Kegunaan, 
Persepsi Kemudahan, and Sikap Penggunaan Terhadap Minat Perilaku Penggunaan Billing System. Jurnal Mahasiswa Perpajakan. Jurnal.

10. Bhanugopan, R. and Fish, A. (2006), An Empirical Investigation of Job Burnout Among Expatriates, Personnel Review, Vol. 35, No. 4, hal. 449-468.

11. Cordes, L., C., Dougherty, \& W., T. (1993). A Review and An Integration of Research On Job Burnout. Academy of Management Review. Academy of Management Review, 18, 621-656.

12. Davis,F.D. 1989. "Perceived Usefulness, Perceived Ease of Use, and User Acceptance of Information Technology". MIS Quarterly.Vol. 13 No. 5.

13. Ferdiansyah, Ira Rachmawati Purnima. 2011. Pengaruh Role Conflict, Role Ambiguity, Role Overload Terhadap Burnout (Study Empiris pada Auditor di KAP Kota Bandung. Jurnal Manajemen and Akuntansi. Vol. III No.2

14. Feist, Jess. Feist, Gregory. J. 2000. Teori Kepribadian Edisi 7. Jakarta: Penerbit Salemba Humanika.

15. Feist, J., \& Feist., G. J. (2000). Theories of Personality (Edisi Keenam). Yogyakarta: Pustaka Pelajar. Yogyakarta: Pustaka Belajar.

16. Fogarty, Timothy, J., Singh., J., Rhoads, G. K., \& Moore, R. K. (2000). Antecedents and Consequences of Burnout in Accounting: Beyond The Role Stress Model. Behavioral Research in Accounting, 12(2), 31-67.

17. Freudenberger, H. (1974). Staff Burnout. Journal of Social Issue, 30, 159-165.

18. Govindarajan, V. 1986. Impact of Participation in the Budgetary Process on Managerial Attitudes and Performance: Universalistic and Contingency Perspective. Decision Science 17. Hal. 396-516.

19. Ghozali, I. (2016). Aplikasi Analisis Multivariate dengan Program SPSS. Edisi ke 7. Semarang: Universitas Diponegoro.

20. Gratia, a. A. (2014). Pengaruh Gaya Hidup Sehat Terhadap Psychological Well-Being and Dampaknya Pada Auditor KAP ( Studi Empiris pada Auditor Kantor Akuntan Publik di Jawa Tengah and DIY ). Hal: 66.

21. Heider, Fritz. 1958. The Psychology of Interpersonal Relations, New York: Wiley.

22. Husnurrosyidah and Suhadi. 2017. Pengaruh E-Filing, e-Billing and e-Faktur Terhadap Kepatuhan Pajak pada BMT Se-Kabupaten Kudus. Jurnal Analisa Akuntansi and Perpajakan. Vol.1 No.1 Hal 97-106

23. Jogiyanto. (2007). Sistem Informasi Keperilakuan. Yogyakarta: Andi Offset.

24. Jones, A. E. AL. (2010). Healthy Lifestyle as a Coping Mechanism for Role Stress in Public Accounting. Behavioral Research In Accounting, 22, 21-41.

25. Jung, C.G. 1960. The Structure and Dynamic of Psyche. New Jersey: Princenton University Pres.

26. Kania, P., Wahyuni, A., Luh, N., Erni, G., \& Arie, M. (2017). Pengaruh Penerapan ESystem Perpajakan Terhadap Tingkat Kepatuhan Wajib Pajak Orang Pribadi Dalam Membayar Pajak Pada Kantor Pelayanan Pajak (Kpp) Pratama Singaraja, 7(1)

27. Kreitner, R., \& Kinicki, A. (2005). Perilaku Organisasi, Buku 1 edisi 5. Salemba Empat.

28. Maslach, C., \& Jackson, S. . (1981). The measurement of experienced burnout. Journal Of Occupational Behaviour. Journal Of Occupational Behaviour, 2, 99-113.

29. Meity, Muhrani Putri. 2018. Pengaruh E-Filing, E-Biliing, and E-Tax terhadap Kepatuhan Wajib Pajak. Skripsi. Fakultas Ekonomi Universitas Islam Indonesia. Yogyakarta.

30. Mondy, Sharplin, and Premeaux. 1990. Management and Organizational Behavior. McGraw Hill.

31. Murray, Dennis. 1990. The Performance Effects of Participative Budgeting: An Integration of Interventing and Moderating Variables. Behavior Research In Accounting, Vol. 2 .

32. Murtiasri, E., \& Ghozali, I. (2006). Anteseden and Konsekuensi Burnout pada Auditor: Pengembangan terhadap Role Stress Model. Simposium Nasional Akuntansi IX, 1-27.

33. Mustafa, H. (2011). Perilaku Manusia dalam Perspektif Psikologi Sosial. Jurnal Administrasi Bisnis, 7(2), 143-156.

34. Nurhidayah, Sari. (2015). Pengaruh Penerapan Sistem E-Filing Terhadap Kepatuhan 
Wajib Pajak Dengan Pemahaman Internet Sebagai Variabel Pemoderasi Pada Kpp Pratama Klaten. Fakultas Ekonomi Universitas Negeri Yogyakarta.

35. Pandiangan, Liberti, 2008, Modernisasi and Reformasi Pelayanan Perpajakan Berdasarkan Undang-Undang Terbaru, PT Elex Media Komputindo, Jakarta.

36. Pines, A., \& Maslach, C. (1993). Characteristics of Staff Burnout in Mental Health Settings. Hospital Community Psychiatry, 29, 233-237.

37. Ray, E. B., and Miller, K. I. 1994. Social Support, Home Work Stress, and Burnout: Who Can Help. Journal of Applied Behavioral Science. 30: Hal : 357-373.

38. Resky Wahyuni. 2015. Pengaruh Persepsi Kegunaan, Kemudahan, Keamanan and Kerahasiaan, and Kecepatan Terhadap Intensitas Perilaku Dalam Penggunaan E-Filing (Studi Pada Wajib Pajak Orang Pribadi di Kantor Pelayanan Pajak Pratama Pekanbaru Senapelan).

39. Robbins, S. P., Judge, A., \& A, T. (2008). Perilaku Organisasi. Jakarta: Salemba Empat.

40. Rakhmansyah, Hikmat (2010). Pengaruh Penerapan e-SPT Digital Terhadap Efektivitas Pemrosesan Data Perpajakan Menurut Persepsi WP Badan. Skripsi: Fakultas Ekonomi, Universitas Padjadjaran, Bandung

41. Riantiningtyas, A. (2009). Pengaruh Role Stressors and Self Esteem terhadap Timbulnya Burnout and Konsekuensinya terhadap Job Outcomes Auditor di Indonesia. Ejournal Universitas Diponegoro.

42. Sarwono, S. . (2015). Teori-Teori Psikologi Sosial. Jakarta: Rajawali Press.

43. Schick, A. G., Gordon, L. A., \& Haka, S. (1990). Information Approach: A Temporal Approach. Accounting, Organizations and Society. Accounting, Organizations and Society, 15(3), 199-220.

44. Solimun. (2010). Analisis Multivariat Pemodelan Struktural Metode Partial Least SquarePLS. Malang: CV. Citra.

45. Sudibyo, I. (2011). Anteseden and Konsekuen Computer Anxiety. Universitas Katolik Soegijapranata.

46. Sulistyorini, Ari Purwoko. 2017. Wahyu Prihantini. IPA Terpadu SMP Kelas VII. Jakarta: Ghalia Indonesia Printing.

47. Suryabrata, Sumadi. (2013). Metodologi Penelitian. Jakarta: Rajawali Pers

48. Sukmarini, Nenny. (2007). Pengaruh Penerapan SPT Digital Terhadap Efektivitas Pemrosesan Data Perpajakan Menurut Persepsi WP Badan. Skripsi: Fakultas Ekonomi, Universitas Padjadjaran, Bandung.

49. Suryadi, Rendy. (2012). Pengaruh Penerapan e-SPT Terhadap Efektivitas Pemrosesan Data Perpajakan Menurut Persepsi Wajib Pajak: Survey Terhadap Pengusaha Kena Pajak Pada KPP Pratama Majalaya. Skripsi: Fakultas Ekonomi, Universitas Kristen Maranatha, Bandung.

50. Sugiyono. 2017. Metode Penelitian Kuantitatif, Kualitatif, and Kombinasi (Mixed Methods). Bandung: Alfabeta.

51. Suliman, A. M., Abdel Rahman, A. A., \& Abdalla, A. (2010). Personality traits and work performance in a duty-free industry. International Journal of Commerce and Management, 20(1), 64-82.

52. Suryabrata, S. (2003). Psikologi Kepribadian. Jakarta: Rajawali Press.

53. Tamaela, E. Y. (2011). Konsekuensi Konflik Peran, Kelebihan Beban Kerja and Motivasi Intrinsik terhadap Burnout pada Dosen yang Merangkap Jabatan Struktural. Jurnal Aset, Vol 3 (2).

54. Utami, I., \& Nahartyo, E. (2013). The Effect of Type A Personality on Auditor Burnout: Evidence from Indonesia. Accounting and Taxation, 5(2), 89-103. https://doi.org/10.1016/S0223-5234(97)89089-7.

55. Wiryathi, N. M., Rasmini, N. K., \& Wirakusuma, M. G. (2014). Pengaruh Role Stressors pada Burnout Auditor dengan Kecerdasan Emosional Sebagai Fakultas Ekonomi and Bisnis Universitas Udayana, 5, 227-244.

56. Yustrianthe, R. H. (2008). Pengaruh Flexible Work Arrangement terhadap Role Conflict, Role Overload, Reduced Personal Accomplishment, Job Satisfaction and Intention to Stay. Jurnal Bisnis and Akuntansi, 10(3), 127-138. 